\title{
ВПЛИВ КОНЕКСТУ НА АКТУАЛІЗАЦІЮ СИНОНІМІЧНИХ ЗНАЧЕНЬ У ТВОРАХ СУЧАСНИХ УКРАЇНСЬКИХ ПИСЬМЕННИКІВ
}

\author{
Людмила Семак \\ Дніпровський державний аграрно-економічний університет \\ ДніпроУкраїна \\ ORCID: 000-0002-2495-4680
}

\section{THE INFLUENCE OF THE CONTEXT ON THE ACTUALISATION OF SYNONYMUS MEANINGS IN MODERN UKRAINIAN FEMALE PROSE}

\begin{abstract}
This paper is devoted to synonyms that function in the texts of modern Ukrainian female prose. The meanings of lexical units that enter into synonymous relations under the certain contextual conditions are analyzed. The semantic processes during which there is a semantic variation in meanings of synonyms are given. Using the method of component analysis, the semantic composition of the meanings of synonyms is described: the integral, differential and occasional components of the semantics of synonyms are revealed. The peculiarities of the transformation of the seme structure of words meanings under the context influence are clarified. It is emphasized that words meaning under the influence of the context undergoes certain changes, which determines the promotion of synonymous relations.
\end{abstract}

Key words: synonym, semantic structure of the word meaning, seme, actual meaning of the word, modern Ukrainian female prose

У лінгвоукраїністиці кінця XX - початку XXI ст. спостерігаємо відродження й посилення інтересу до вивчення синоніміки, що зумовлено переорієнтацією лексикоцентричного мовознавства в напрямку тексто- й дискурсоцентризму. Усе частіше науковці звертаються до аналізу функціонально-семантичних особливостей синонімів, оскільки їхні значення в лінгвальній системі та у виявах мовної діяльності істотно відрізняються. Через це помітним $є$ певне зміщення акцентів у дослідженні лексичної синонімії - від узуального плану до контекстуального іiї втілення. Застосування нових методів аналізу художнього тексту загалом дає змогу розглянути авторські новації, що $є$ наслідком контекстуального словозближення, виявити особливості функціонування лексичної синоніміки української мови на початку XXI ст.

Проблема лексичних синонімів давно привернула увагу науковців. Ïї активно досліджували українські (Вероніка Басок, Віктор Левицький, 
Ніна Пашковська, Лев Полюга, Олександр Тараненко, Людмила Терещенко та ін.) і закордонні (Юрій Апресян, Стефан Ульманн, Йозеф Філіпец, Гуго Ернст Маріо Шухардт та ін.) лінгвісти. Утім, лексична синонімія залишається предметом наукових дискусій, оскільки досі немає одностайного погляду підстави виникнення синонімічних відношень між лінгвальними одиницями в мовному узусі та в художньому тексті, повною мірою не окреслена роль сучасних українських письменників і письменниць.

Сучасна українська жіноча проза - помітне явище в українській літературі. Її презентують твори таких письменниць, як Ніна Бічуя, Марина Гримич, Люко Дашвар, Оксана Забужко, Ірена Карпа, Свгенія Кононенко, Марія Матіос та ін. Сучасну українську жіночу прозу глибоко вивчають літературознавці, критики, лінгвісти, зокрема Віра Агеєва, Тетяна Должикова, Юлія Кушнерюк, Лариса Мацько, Галина Рижкова, Світлана Філоненко, Роксолана Харчук, інші дослідники, які вже досить чітко окреслили жіночу манеру письма і вписали цілісний феномен в український лінгвокультурний простір. Попри зацікавлення науковців тими чи тими складниками ідіолектів окремих письменниць, що виконують найрізноманітніші експресивно-естетичні й оцінні функції, багато лінгвальних одиниць їхніх художніх текстів потребують докладнішого обгрунтування. Поки що не стали предметом системних лінгвістичних досліджень і лексичні синоніми, що по-особливому маркують тексти сучасних українських письменниць, у межах яких вони семантично та функціонально значущі.

Актуальність пропонованої статті зумовлена потребою описати синоніми, що постають у художніх текстах сучасних українських письменниць на підставі трансформації семного складу значень слів під впливом контексту. Мета статті - здійснити опис лексичних синонімів, що фігурують у текстах українських прозаїкинь, проаналізувати семантичні процеси, що відбуваються у семному складі лексичних значень синонімів під впливом контексту. У розвідці використано загальнонаукові методи спостереження, аналізу, синтезу, порівняння; лінгвістичні методи, серед яких традиційний описовий метод - для витлумачення сутності явища лексичної синонімії; метод компонентного аналізу, застосований для ідентифікації лексичних значень синонімів, що в контекстах зазнали трансформації внутрішньої форми або розширили свою семантичну структуру.

Відомо, що в сучасному мовознавстві прийнято розглядати загальномовні та контекстуальні синоніми. Під загальномовними (узуальними) синонімами розуміють зближені слова в основному значенні, що мають здатність взаємозамінюватися, характеризуються достатньою частотністю вживання, нормативністю, відносною незалежністю від контексту. 
Такі синоніми зафіксовані в тлумачних і синонімічних словниках. Контекстуальними синонімами називають словозближення, що відбувається лише в поодиноких випадках, в обмеженому контексті, залежить від цілей та інтенцій адресанта. Відмінною ознакою таких синонімів $є$ їхня контекстуальна зумовлюваність, невідтворюваність такого синонімічного ряду, обмеженість уживання, одиничність семантики і відсутність у словниках. Контекстуальну синонімію визначають як "явище, що передбачає референтну ідентичність, семантичну схожість, єдність функціонально-стилістичних показників та однакове прагматичне спрямування номінативних одиниць, які синонімізувалися в контексті"' ${ }^{1}$. Семантичний зв'язок між контекстуальними синонімами встановлють завдяки їх суміжності, функціональній схожості, синтагматичним, парадигматичним і асоціативним зв'язкам.

Найменш дослідженим досі залишається аспект близькозначності мовних одиниць у контексті художнього твору, семантичні ознаки синонімів, які постають у сучасній українській жіночій прозі. Художній текст і контекст сприяють реалізації певного - первинного чи метафоричного, подеколи навіть нового, значення слова і на цій основі синонімізації значень слів. Так, у реченні Зате твої жаркі слова стинають мечами - радісними і визвольними (Чотири пори життя) ${ }^{2}$ виділені слова зближуються за значенням у контексті. Радісний має закріплене словникове значення "який приносить, дає радість, втіху" (СУМ)․․ Слово визвольний розвиває схоже значення лише за певних комунікативних умов, коли опиняється поряд 3 прикметником радісний і стає означенням до мечі. Визвольний усвідомлюється як той, що звільняє з неволі, а тому отримує значення "який утішний; відрадний".

У мові творів сучасних українських письменниць постійно натрапляємо на контекстуальні синоніми, що виникають завдяки розширенню семантичної структури їхніх лексичних значень. Наприклад, у реченні Адже й така, невагома, безтілесна, бездушна, я чую на собі тягар, вагу, вантаж (Чотири пори життя) $)^{4}$ синонімічний ряд утворюють зазвичай не близькозначні слова невагомий - безтілесний - бездуиний лише тому, що контекстуальна синонімія підтримується поданою далі узуальною синонімічною парадигмою тягар - вага - вантаж; у синтаксичній контрукції - Навіщо там так наполегливо намагалися зробити з мене зомбі ціною великих зусиль $i$ затрат, моїх особистих потрясінь

В. Басок, Контекстуальна синонімія: семантики-стилістичний та прагматичний аспекти (на матеріалі іменників сучасної німецької мови: автореф. дис. ... канд. філол. н. : 10.02.04, Київ 2006, с. 8.

М. Матіос, Чотири пори життя, Львів 2009, с. 31.

Словник украӥнської мови: в 11 томах, т. 5, Київ 1970-1980, с. 372.

4 М. Матіос, Чотири пори життя, Львів 2009, с. 31. 
і розпуки, коли тут ие відбувається безболісно і швидко? (Чотири пори життя) $)^{5}$ зафіксовано три синонімічні пари, першу з яких можна вважати наслідком узуального зближення значень слів, що в контексті вжиті 3 метою уточнення дії. Друга пара ситуативно синонімізується для передання значення “сильний душевний біль” на основі інтегральної семи ‘сила вияву'. Третя пара $є$ оказіональною і сприймається як синонімічна, оскільки виникає як асоціативне семантичне протиставлення до попередніх синонімічних рядів. У зв'язку з дискурсивною ситуацією там, наполегливо, тобто довго, а тут - безболісно й швидко, слова розвивають спільне оказіональне значення "який не супроводжується ускладненнями” на основі інтегральної семи 'спосіб дії'.

Різнотипні семантичні зрушення притаманні й для багатьох інших слів, що вступають в синонімічні відношення лише в певному контексті. Наприклад: Це, певно, земні мої вантажі, неодноразово прокляті і проплакані ноші, тиснуть мене й по смерті (Чотири пори жсття) ${ }^{6} ;$ У такому мерхлому насвітленні, де розмивається фактура деталей, $i$ справдi молода, $і$ надзвичайно, палюче вродлива, аж лячно: щось відьомське, поганське (Музей покинутих секретів) ${ }^{7}$. У наведеному контексті синонімізуються слова проклятий - проплаканий, у структурі значень яких виникає спільний компонент 'який приносить досаду'. Контекстуальний вияв синоніма проплаканий потрібно розглядати як авторський, такий, що має оказіональне значення й набуває його через зближення 3 прикметником проклятий, оскільки те, що засуджують і ненавидять, зазвичай докучає й може викликати сльози.

Поява синонімів зумовлена семантичними процесами, що виникають під час взаємодії значень мовних одиниць у художніх текстах. Семантична структура лексичних значень синонімів репрезентує семний склад з урахуванням контекстуальних зв' язків. Вона зазвичай складається з класем, архісем, інтегральних, диференційних, потенційних і оказіональних сем. Класеми, архісеми і диференційні семи зараховуємо до ядерних, а інтегральні, потенційні, приховані й оказіональні - до периферійних складників семантичної структури значення слова (за класифікацією Йосифа Стерніна) ${ }^{8}$. Ядерні і периферійні семи формують денотативний компонент структури значення контекстуальних синонімів. Ядерні семи синонімів - це основні, найістотніші складники значення, що зближують слова. Ядерні семи позначають постійні, невіддільні ознаки поняття. Пе-

Там само, с. 18.

Там само, с. 72.

О. Забужко, Музей покинутих секретів, вид. 2-е, доп. Київ 2009, с. 184.

И. Стернин, Лексическое значение слова в речи (коммуникативный аспект), Воронеж 1985 , с. 75. 
риферійні семи позначають менш істотні, непостійні, ймовірні ознаки поняття, що не $є$ для нього основними. Ядерні семи (класеми, архісеми, диференційні семи) значень контекстуальних синонімів стали основою для зближення. Периферійні семи (інтегральні, приховані, гіперсеми, гіпосеми, оказіональні) теж важливі, оскільки вони актуалізуються під час мовної діяльності автора, надають образності й експресивності контекстуальним синонімам, стають основою їхніх похідних метафоричних значень, розширюють номінативні можливості.

Отже, значення слова у контексті зазнає істотних змін. Науковець Й. Стернін зауважує, що “контекст виконує кілька функцій щодо семантики слова, які по-різному репрезентуються в мовній діяльності адресанта й адресата мовної діяльності"”. Для адресанта мовної діяльності контекст виконує функцію актуалізації, тобто відбиває через формальні засоби комунікативні наміри мовця, а для адресата - розпізнавальну. Звідси можна припустити, що автор зазвичай розширює межі семантичного простору в художньому тексті за рахунок семантики контекстуальних синонімів, з метою актуалізації особливого, потрібного йому в цій мовній ситуації, значення слова. Таке значення прийнято називати актуальним смислом слова.

Утворення актуального смислу слова - це контекстуально зумовлене семне варіювання значення, сутність якого розкривається в реалізації комунікативно релевантних складових значення слова. Набір сем, що підлягають актуалізації, визначається комунікативним завданням автора у художньому тексті. Актуальний смисл слова в тексті привноситься не лексичною одиницею, а дотриманням художньої мети, контекстом. Контекст установлює актуальний смисл, тобто сукупність сем значення, що актулізуються в конкретному висловленні. У художньому тексті ядерні і периферійні семи можуть реалізуватися не повністю, в різних поєднаннях одна з одною - залежно від художнього контексту. Контекст реалізовує конкретні семи потрібного значення певної одиниці синонімічного ряду, що виступає в художньому тексті як комунікативно-релевантне, запрограмоване комунікативним наміром автора, тобто формує актуальний смисл слова під час мовної діяльності.

Отже, упорядкувати контекстуальні синоніми у функціонально-семантичні класи і функціонально-семантичні групи дозволила не лише універсальність, варіативність і однопорядковість лексичної синоніміки, а обов'язкова властивість синонімів - потрапляти під час мовної діяльності під уплив контексту. У контексті художнього твору синонім з визначеним словниковим значенням перетворюється на одиницю з актуалізованим значенням. Наприклад, у висловленні Їй (Редьизі) відчинили не

9 Там само, с. 81. 
відразу. Видно, довго й прискіпливо розглядали спершу на відео моніторі (Піиа “Гімалаї”) ${ }^{10}$ письменниця Ірена Карпа контекстуально синонімізує слова довго - прискіпливо на позначення дії, що потребує вимогливості, тому займає тривалий відрізок часу. При цьому контекст, у якому реалізовано одиниці ситуативного синонімічного ряду, тобто відбувається їх актуалізація, цінний тим, що істотно розширює виражальні можливості синонімів: другий синонім ряду уточнює значення першого, відбиває часову локалізацію.

У лінійному контексті художнього твору семний склад значення слів зазнає змін, іноді серйозних, відбиваючи нове синонімізоване конкретне значення відповідно до цієї контекстуальної ситуації. Жодна мовна одиниця, лексико-синонімічна зокрема, не може бути осмислена і засвоєна поза контекстом, без урахування тих одиниць, що їі оточують, на тлі яких вона постає у висловленні. Тобто якраз під упливом семантичних процесів контексту відбувається їх семне варіювання.

Семне варіювання значення за критерієм семного наповнення контекстуальних синонімів передбачає здійснення таких семантичних процесів:

1. Актуалізація семи - це комунікативно зумовлене виділення семи в семантичній структурі значення, що розвиває іiі актуальний смисл. Актуалізуватися можуть і ядерні, і периферійні семи семантичної структури значення контекстуальних синонімів. Усталені актуальні смисли, що постають унаслідок актуалізації ядерного компонента семантичної структури значень ситуативних синонімів, у художньому тексті не мають жодних формальних показників. Наприклад: Дуже далеко, високо, але Редьиі зробилося від того раптом добре (Піиа "Гімалаї")"1. За Словником української мови: високо - "присл. від який має велику відстань знизу вгору”12, а далеко - “присл. від який має велику відстань знизу вгору”"13. Реалізація синонімічних відношень у контексті стає можливою через закріплену в ядрі значення архісему 'відстань' та актуалізацію диференційної семи 'напрямок'. Синонімізація задіює відповідну сему з метою уточнення контексту.

Актуалізація периферійних сем відбувається через різні формальні сигналізатори, як-от, використання поряд з художніми засобами, графічне оформлення висловлення та ін. Так, у реченні Від нього пахло хмарами. Пахло небом і простором (Шпага Славка Беркути) ${ }^{14}$ загальномовних синонімів немає, проте близькозначність створюється за умови

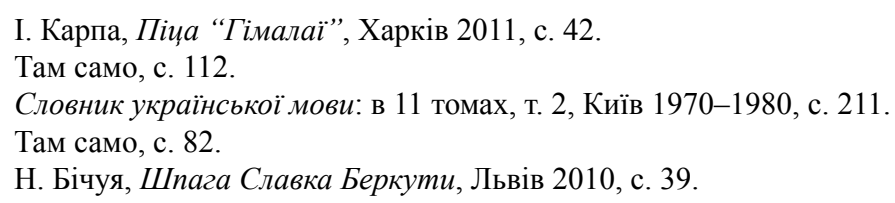


оформлення контексту і поступу інтегральної семи 'обшир'. Ці лексеми через актуалізацію периферійної семи передали спільне значення “необмежена протяжність над землею" у контексті.

2. Підсилення семи - наростання інтенсивності семи в межах семантичної структури значення. Певна сема може бути панівною у семантичній структурі й відігравати головну роль у реалізації словом актуального смислу. Наприклад: Перехмарилося, передощило - $i$ серед глухої осені настала суховітриия, трапився ясний, теплуватий день, мовби заблукав, не на своє місие потрапив (Шпага Славка Беркути) ${ }^{15}$. Такі слова розвивають спільне значення "пройти, минутися" на основі підхожої ядерної архісеми 'дія'. Через уживання префікса пере- актуалізують диференційну сему 'доконаний спосіб дії' та потенційну сему 'інтенсивність', чим підвищують напруженість у висловленні. Усі інші складники семантичної структури контекстуальних синонімів займають другорядну позицію, тому істотної інформації не відбивають.

3. Спад семи - процес, зворотній до вище описаного - зменшення інтенсивності вияву семи у семантичній структурі значення синонімів. Такі семи не можуть реалізувати повною мірою актуального смислу слова, тому замінюються новими. Наприклад: Я розумію, щзо не всесильний $i$ не всевладний (Зрада. ZRADA made in Ukraine) ${ }^{16}$. Всесильний і всевладний синонімізуються з метою передання значення "той, який має необмежену силу”. Однак, через вживання заперечної частки не контекстуальні синоніми трансформують свою семантичну структуру: архісема 'сила вияву' спадає, зумовлюючи актуалізацію потенційної семи 'відсутність вияву ознаки'.

4. Підтримання семи - це вербальна постановка семи, що актуалізується в художньому дискурсі. Вона зазнає поступу в семантичній структурі контекстуальних синонімів, щоб пояснити значення художніх символів, образів. Така постановка $є$ засобом контекстуального моделювання семи, полягає у вживанні в художньому тексті слова чи словосполучення (пояснення), тотожного з окремою семою, що актуалізується, або актуальним смислом слова загалом. Найчастіше такої підтримки і постановки потребують периферійні семи, оскільки саме вони можуть спровокувати неясність. У реченні Добрі три-чотири години вони підіймались вузенькою піщаною стежиною над прірвою, чиї краї підступно поросли густою соковитою травою (Піия “Гімалаї”) ${ }^{17}$ актуальний смисл синонімізації густий - соковитий представлений значенням "яскраво виражений вияв ознаки”, що розпізнається у контексті лише у зв’язку з іменником трава.

Там само, с. 96.

Є. Кононенко, Зрада. ZRADA made in Ukraine, Львів 2002, с. 71.

I. Карпа, Піца “Гімалаї”, Харків 2011, с. 61. 
5. Розщеплення семи - актуалізація лише іiі частини, що розвивається за умов переносного вживання слів - метафорі, метонімії тощо. Наприклад: Ще з годину тому на ичегляних вуличках верещало, варилося й продавалося, а тепер таке враження, наче останні люди покинули їх зо півтисячоліття тому (Піиа "Гімалаї") ${ }^{18}$. Переносне значення полісемантичного слова варитися "бути неспокійним, тривожним, чекаючи” актуалізує потенційні семи 'дія, на позначення існування', чим зумовлює синонімізацію слів.

6. Уточнення семи - це визначений комунікативним завданням перехід мовця від абстрактної семи до конкретної у семантичній структурі значення синонімів. Цей процес супроводжує актуалізацію семи, він стосується лише абстрактних сем, оскільки конкретні семи додаткової специфікації не потребують. Наприклад: Я знав, що в житті мусить бути щось фесричне, дике, незбагненне (Чотири пори життя) ${ }^{19}$. Абстрактна сема незвичайності потребує уточнення. У цьому контексті конкретизується значення синоніма феєричний через актуалізацію семи 'нестримність' у значенні синоніма дикий. Уточнення значення - це зазвичай лексична перебудова: слово ширшої семантики загального лексичного значення конкретизується словом вужчої.

7. Наведення семи - це привнесення контекстом семи, відсутньої в узуальному значенні слова. Наприклад: $B u$, на землі, змімуєте два поняття: перше: Бог - Творець і Вседержнитель, а друге - це той імідж, який йому створили різні релігії, тобто Бог як об'єкт поклоніння, ідол (Second life (Друге життя) ${ }^{20}$. У слові творець наводиться невідома словниковому значенню сема 'надприродна істота', що, у зв'язку з уточненням бог, зумовлює синонімізацію слів у контексті.

8. Категоризація значення - комунікативно зумовлений вибір архісеми для актуалізованого значення. Архісема обирається з відкритої низки архісем, що вже закріплені у значенні через попередній досвід категоризацій. Вибір архісеми постає в мовній діяльності автора, під час продукування художнього тексту, однак це не означає, що така сема наводиться контекстом. У реченні Адька сказав, щңоб вона не журилася, він її прогодує, - не без гордої нотки в голосі сказав, чи принаймні ій так здалося, і вона й на нього образилася, вгледівши в тому класичний чоловічий егоїзм: знайшов коли хвастати своєю фінансовою потентністю! - а він, може, $і$ в гадиі не мав хвастати, ие з неї несподівано полізла, як паста з придавленого тюбика, ранена підозріливість до всіх і вся, питома риса всіх принижених $і$ беззахисних, швидко ж вона увійшла в ию роль!..

\footnotetext{
Там само, с. 30.

М. Матіос, Чотири пори життя, Львів 2009, с. 31.

М. Гримич, Second life (Друге життя), Київ 2010, с. 53.
} 
(Музей покинутих секретів $)^{21}$. За Словником украӥнської мови: принижений - "пригноблений, безправний”22, а беззахисний - "який не може захистити себе; безпорадний, безпомічний" "23. Автор зближує значеннями слова через категоризацію семи 'відсутність захисту', оскільки загалом зрозуміло, що того, хто не має захисту, легко принизити, позбавити прав.

Отже, у межах контексту слово набуває здатності розширювати свою семантичну структуру, набуваючи у зв'язку з іншими вжитими словами нових лексичних значень. Вплив контексту зумовлює певні зрушення у семантичній структурі значень синонімів. У мові творів сучасних українських письменниць постійно натрапляємо на контекстуальні синоніми, що виникають завдяки варіюванню семного складу їхніх лексичних значень. У контексті художніх творів прозаїкинь синоніми можуть актуалізувати потрібні смисли, спираючись на основні семантичні процеси: актуалізацію, підсилення, послаблення, підтримання, модифікацію, наведення, конкретизацію сем, а також категоризацію значення. Синоніми, потрапляючи в контекстуальну залежність, постають одним із дієвих засобів донесення інформації від авторок до читача, відбиття охудожненої дійсності.

\section{БІБЛІОГРАФІЯ}

Basok Veronika. 2006. Kontekstual'na sinonìmiâ: semantiki-stilističnij ta pragmatičnij aspekti (na materialì imennikìv sučasnoï nìmec'koï movi): avtoref. dis. ... kand. filol. n.: 10.02.04. Kiїv [Басок Вероніка. 2006. Контекстуальна синонімія: семантики-стилістичний та прагматичний аспекти (на матеріалі іменників сучасної німецької мови): автореф. дис. ... канд. філол. н.: 10.02.04. Київ].

Bǐčuâ Nìna. 2010. Spaga Slavka Berkuti. L'vìv: Vidavnictvo Starogo Leva [Бічуя Ніна. 2010. Шпага Славка Беркути. Львів: Видавництво Старого Лева].

Grimič Mariâ. 2010. Second life (Druge žittâ). Kiïv: Dulibi [Гримич Марія. 2010. Second life (Друге життя). Київ: Дуліби].

Karpa İrena. 2011. Pica "Gìmalaī". Harkìv: Knižkovij klub "Klub sìmejnogo dozvìllâ" [Карпа Ірена. 2011. Піияа “Гімалаї”. Харків: Книжковий клуб “Клуб сімейного дозвілля"].

Kononenko Êvgenì̂. 2002. Zrada. ZRADA made in Ukraine. L'vìv: Kal'varìâ [Кононенко Євгенія. 2002. Зрада. ZRADA made in Ukraine. Львів: Кальварія].

Matìos Marìâ. 2009. Čotiri pori žittâ. L'vìv: Pìramìda. 2009 [Матіоc Марія. 2009. Чотири пори життя. Львів: Піраміда. 2009].

Slovnik ukraïns'koï movi: v 11 tomah. 1970-1980. Red. Bìlodìd Ì. Kï̈v: Naukova dumka [Словник української мови: в 11 томах. 1970-1980. Ред. Білодід І. Київ: Наукова думка].

21 О. Забужко, Музей покинутих секретів, вид. 2-е, доп. Київ 2009, с. 144.

22 Словник української мови: в 11 томах, т. 2, Київ 1970-1980, с. 618.

23 Там само, с. 97. 
Sternin Iosif. 1985. Leksičeskoe značenie slova v reči (kommunikativnyj aspekt). Voronež : Izd-vo Voronež. un-ta [Стернин Иосиф. 1985. Лексическое значение слова в речи (коммуникативный аспект). Воронеж : Изд-во Воронеж. ун-та]

Zabužko Oksana. 2009. Mиzej pokinutih sekretiv. Vid. 2-e, dop. Kiїv: Fakt [Забужко

Оксана. 2009. Музей покинутих секретів. Вид. 2-е, доп. Київ: Факт].

\section{WPŁYW KONTEKSTU NA AKTUALIZACJĘ SYNONIMICZNYCH ZNACZEŃ WE WSPÓŁCZESNEJ UKRAIŃSKIEJ PROZIE KOBIECEJ}

Streszczenie: Artykuł przedstawia synonimy funkcjonujące w tekstach współczesnej ukraińskiej prozy kobiecej. Analizowane są znaczenia jednostek leksykalnych wchodzących $\mathrm{w}$ relacje synonimiczne w określonych warunkach kontekstowych. Podano procesy semantyczne, w wyniku których następuje semantyczna wariacja w znaczeniach synonimów. Metodą analizy składowej opisano semantyczną kompozycję znaczeń synonimów: ujawniono całkowe, różnicowe i okazjonalne składowe semantyki wielu bliskich znaczeniowo słów. Wyjaśniono osobliwości transformacji składu rdzeni znaczeń słów pod wpływem kontekstu. Podkreśla się, że znaczenie słów pod wpływem kontekstu ulega pewnym zmianom, które warunkują postęp relacji synonimicznych.

Słowa klucze: synonim, semantyczne znaczenie słowa, sem, rzeczywiste znaczenie słowa, współczesna ukraińska proza kobieca.

\section{ВПЛИВ КОНЕКСТУ НА АКТУАЛІЗАЦІЮ СИНОНІМІЧНИХ ЗНАЧЕНЬ У ТВОРАХ СУЧАСНИХ УКРАЇНСЬКИХ ПИСЬМЕННИКІВ}

Резюме. У статті досліджено синоніми, що функціонують у текстах сучасної української жіночої прози. Проаналізовано значення лексичних одиниць, що вступають у синонімічні відношення за певних контекстуальних умов. Наведено семантичні процеси, за яких відбувається семне варіювання у значеннях синонімів. За допомогою методу компонентного аналізу описано семний склад значень синонімів: виявлено інтегральні, диференційні й оказіональні складники семантики низки близьких за значенням слів. 3'ясовано особливості трансформації семного складу значень слів під впливом контексту. Наголошено, що значення слів під впливом контексту зазнає певних зрушень, що зумовлює поступ синонімічних відношень.

Ключові слова: синонім, семний склад значення слова, сема, актуальний смисл слова, сучасна українська жіноча проза 